This is an open access article under the CC BY-NC-ND license

Issue IV, 22 November 2021

e-ISSN 2707-9481

Institute of Metallurgy and Ore Beneficiation, Satbayev University, Almaty, Kazakhstan

\author{
Abdulvaliyev Rinat Anvarbekovich \\ Cand.tech.sc., head of the laboratory of alumina and \\ aluminum. JSC "Institute of Metallurgy and Ore \\ Beneficiation", Satbayev University Almaty, Kazakhstan \\ Email: r.abdulvaliyev@satbayev.university \\ ORCID ID: 0000-0001-6747-6984
}

Akcil Ata

Eng.Group Leader, MMRR Research Group, Suleyman Demirel University, Isparta, Turkey

Email:ataakcil@sdu.edu.tr

ORCID ID: 0000-0002-9991-0543

\title{
Change in the phase composition of low-quality bauxites as a result of chemical activation
}

\begin{abstract}
As a result of separation of a fine fraction of gibbsite-kaolinite low-quality bauxite from the Krasnogorsky deposit, it is possible to increase its silicon module. When bauxite is chemically activated in a solution of sodium bicarbonate, the fine fraction is effectively separated from the large one and the phase composition changes - the calcium silicate phase disappears and the calcite phase is formed. With an increase in the activation temperature, the content of kaolinite and siderite decreases, the content of quartz and hematite increases. Studies have shown that at chemical activation temperatures of $120{ }^{\circ} \mathrm{C}$, lasting more than 120 minutes and $200{ }^{\circ} \mathrm{C}$, lasting more than 40 minutes, a dawsonite phase is formed in bauxite, which compacts the mineral structure. When determining the mode of chemical activation, it is necessary to take into account the negative possibility of the formation of dawsonite.
\end{abstract}

Keywords: gibbsite-kaolinite bauxite, chemical activation, sodium bicarbonate, phase composition, conditioning, technology.

Cite this article as: Abdulvaliyev R.A.; Akcil A.; (2021). Change in the phase composition of low-quality bauxites as a result of chemical activation. Challenges of Science. Issue IV, 2021, pp. 67-75. https://doi.org/10.31643/2021.10

\section{Introduction}

Gibbsite-kaolinite bauxites of the Krasnogorsk deposit are characterized by a low silicon modulus and high content of harmful components: siderite, chamosite, hematite, pyrite, organic, and other impurities, and their quality keeps declining, which leads to a sharp deterioration in the composition of solutions, industrial products and a decrease in technical and economic indicators [1]. This circumstance forms the basis for a set of theoretical and technological research to develop effective technology.

It appears practicable to process low-quality bauxites by separate leaching of clay and stony bauxite fractions, but the existing methods of bauxite fraction separation in an alkaline environment do not provide the required degree of separation of the clay part $[2,4]$.

However, the known processing methods applied to low-quality bauxites have many disadvantages that make it difficult or impossible to use them.

To involve most of the bauxite deposits in Kazakhstan in the processing field, a technology for processing low-quality gibbisite-kaolinite bauxites with preliminary chemical activation has been proposed $[3,5,6]$. 


\section{Methods and techniques}

The samples were subjected to a chemical analysis with the help of an optical emission spectrometer with an inductively coupled plasma Optima 2000 DV (USA, Perkin Elmer).

To perform an X-ray fluorescence analysis, a Venus 200 wave dispersion spectrometer (PANalyical B.V., the Netherlands) was used.

The X-ray experimental data were obtained by applying a BRUKERD8 ADVANCE device with copper radiation at an accelerating voltage of $36 \mathrm{~kW}$ and a current of $25 \mathrm{~mA}$.

The X-ray analysis was based on an IR-Fourier spectrometer Avatar 370 in the spectral range of $4000-400 \mathrm{~cm}^{-1}$ from preparations including $200 \mathrm{mg}$ of $\mathrm{KBr}$ and $2 \mathrm{mg}$ of the sample.

A STA 449 F3 Jupiter synchronous thermal analysis instrument was used for the thermal analysis.

A low-vacuum electron microscope with a thermoemission cathode (LaB6) JSM-6610LV from JEOL was applied to take microphotographs.

The chemical activation of bauxite took place in a solution containing $120 \mathrm{~g} / \mathrm{dm}^{3}$ of $\mathrm{NaHCO}_{3}$ at a ratio of $\mathrm{S}: \mathrm{L}=10.0$, temperatures of $90-200^{\circ} \mathrm{C}$ with the help of a thermostated unit with 6 autoclaves rotating through the head, and a working volume of $250 \mathrm{~cm}^{3}$. The required sodium hydrocarbonate content of 120 $\mathrm{g} / \mathrm{dm}^{3}$ in the solution was selected taking into account its solubility limit.

The silicon modulus of the samples was determined based on the $\mathrm{Al}_{2} \mathrm{O}_{3} / \mathrm{SiO}_{2}$ ratio.

\section{Results and discussion}

The study relied on a representative sample of gibbsite-kaolinite bauxite of Krasnogorsk composition, wt. \%: $\mathrm{Al}_{2} \mathrm{O}_{3}$ 42.0; $\mathrm{SiO}_{2}$ 11.5; $\mathrm{Fe}_{2} \mathrm{O}_{3}$ 19.5; $\mathrm{CaO}$ 1.08; $\mathrm{Na}_{2} \mathrm{O}$ 0.22; $\mathrm{MgO} 0.18 ; \mathrm{K}_{2} \mathrm{O} 0.03 ; \mathrm{TiO}_{2}$ 2.05; $\mathrm{SO}_{3} 0.24 ; \mathrm{Cl}-0.04 ;$ p.p. $23.16 ; \mu \mathrm{Si} 3.65$.

Table 1 illustrates the $\mathrm{X}$-ray phase composition of the bauxite sample.

Table 1. The phase composition of the bauxite sample

\begin{tabular}{ccc}
\hline Name & Formula & \% \\
\hline Gibbsite & $\mathrm{Al}(\mathrm{OH})_{3}$ & 54.95 \\
\hline Kaolinite-1A & $\mathrm{Al}_{2} \mathrm{Si}_{2} \mathrm{O}_{5}(\mathrm{OH})_{4}$ & 10.02 \\
\hline Siderite & $\mathrm{FeCO}_{3}$ & 6.09 \\
\hline Hydroaluminosilicate & $\mathrm{Al}_{2} \mathrm{Si}_{2} \mathrm{O}_{5}(\mathrm{OH})_{4}$ & 5.17 \\
\hline Quartz & $\mathrm{SiO}_{2}$ & 5.10 \\
\hline Calcium silicate & $\mathrm{CaS}_{5}$ & 5.07 \\
\hline Hematite & $\mathrm{Fe}_{2} \mathrm{O}_{3}$ & 4.89 \\
\hline Titanium oxide & $\mathrm{TiO}_{2}$ & 4.88 \\
\hline Ferrotitanium oxide & $\mathrm{Fe}_{2} \mathrm{TiO}_{5}$ & 3.83
\end{tabular}

The infrared spectrum of the bauxite sample is shown in Figure 1.

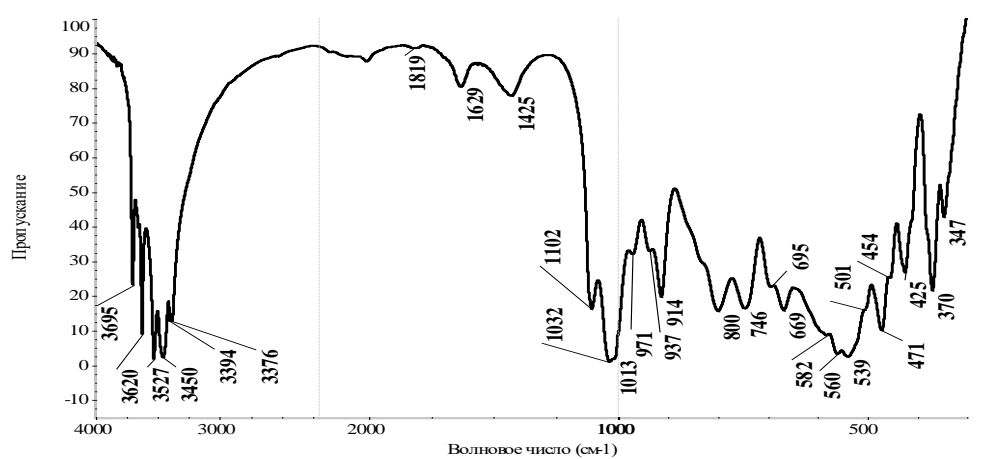

Figure 1. The infrared spectrum of the bauxite sample 
The infrared spectroscopy determined the presence of the following phases: gibbsite $\gamma$-Al $(\mathrm{OH})_{3}$; kaolinite $\mathrm{Al}_{4}\left[(\mathrm{OH})_{8} \mid \mathrm{Si}_{4} \mathrm{O}_{10}\right]$; goethite $\alpha-\mathrm{FeOOH}$; siderite $\mathrm{FeCO}_{3}$. Among those found, there are hematite $\mathrm{Fe}_{2} \mathrm{O}_{3}$; anatase $\mathrm{TiO}_{2}$; diaspore $\alpha-\mathrm{AlOOH}-{ }^{1}$.

The study of the bauxite sample by the thermal method of analysis (Figure 2) showed the following findings: intense endothermic effects with maximum development at $334.5^{\circ} \mathrm{C}, 557^{\circ} \mathrm{C}$ on the DTA curve; additional exothermic effects with peaks at $897.8^{\circ} \mathrm{C}$ and $989.9^{\circ} \mathrm{C}$ on the dDTA curve; minima were recorded at $287.9^{\circ} \mathrm{C}, 319.4^{\circ} \mathrm{C}$, and $532.8^{\circ} \mathrm{C}$ on the DTG curve.

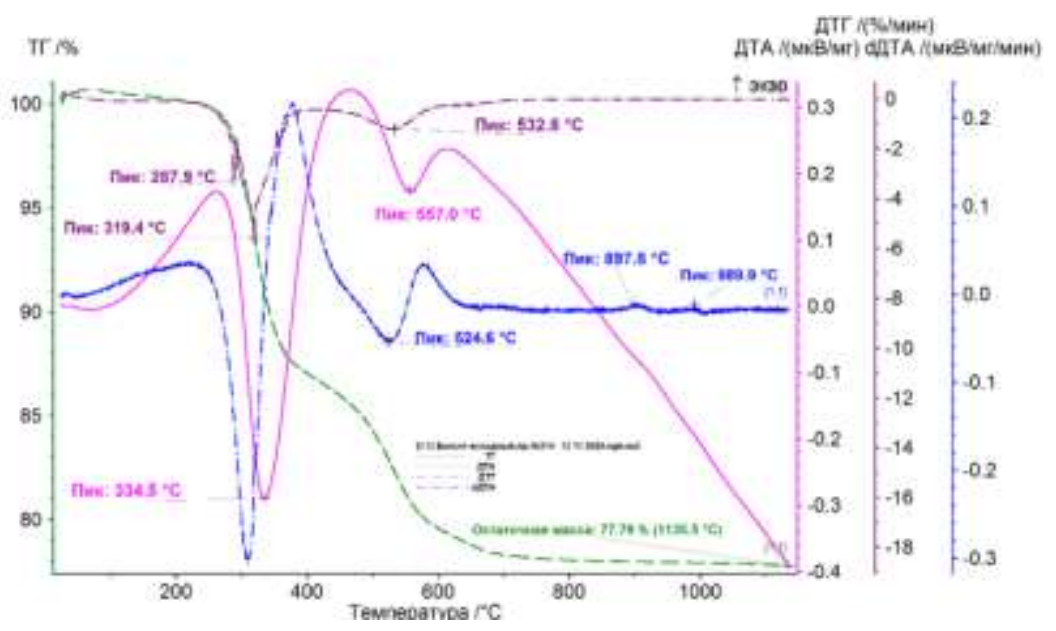

Figure 2. Thermogram of the initial bauxite sample

The deep endothermic effect with maximum development at $334.5^{\circ} \mathrm{C}$, in the development area of which two minima appeared on the DTG curve $\left(287.9^{\circ} \mathrm{C}, 319.4^{\circ} \mathrm{C}\right)$, reflects the dehydration of gibbsite and iron hydroxide. The combination of the endothermic effect with the extremum at $557^{\circ} \mathrm{C}$ on the DTA curve and the weak exothermic effect with the peak at $989.9^{\circ} \mathrm{C}$ on the dDTA curve m.b. the kaolinite manifestation. In superimposition, the combination of the same endothermic effect with the exothermic effect with a peak at $897.8^{\circ} \mathrm{C}$ on the dDTA curve reflects the presence of coarse-grained siderite.

The microphotographs and electron microscopic analysis of the bauxite sample are shown in Figure $3(a, b, c)$.

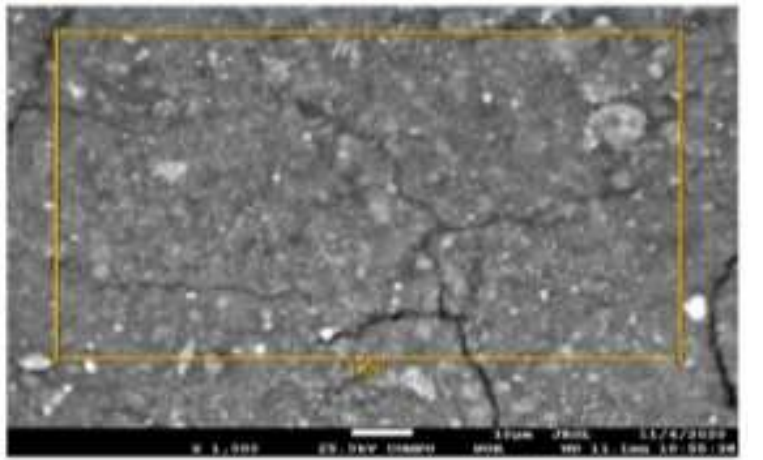

$\begin{array}{ll}\text { Elements } & \mathrm{ms} \% \\ \mathrm{O} & 63.56 \\ \mathrm{Mg}^{*} & 0.08 \\ \mathrm{Al} & 20.20 \\ \mathrm{Si} & 7.14 \\ \mathrm{Cl}^{*} & 0.18 \\ \mathrm{Ca}^{*} & 0.31 \\ \mathrm{Ti} & 0.95 \\ \mathrm{Fe} & 6.87 \\ \mathrm{Cu}^{*} & 0.45 \\ \mathrm{Zn}^{*} & 0.27 \\ \text { Total } & 100.00\end{array}$

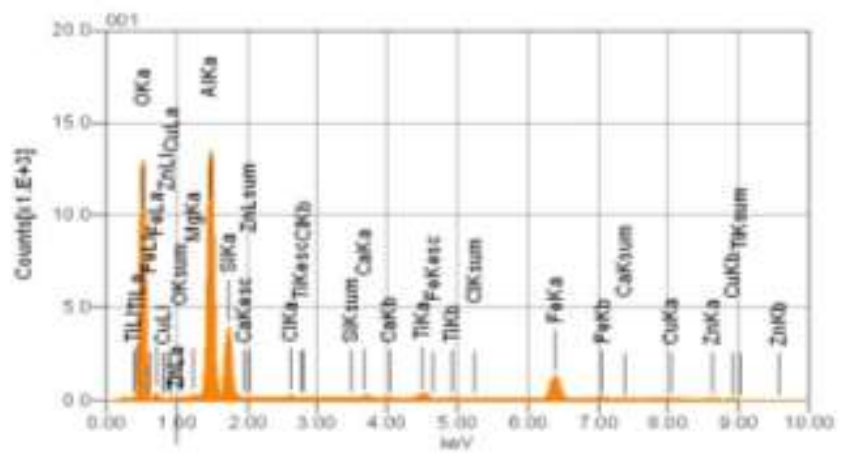



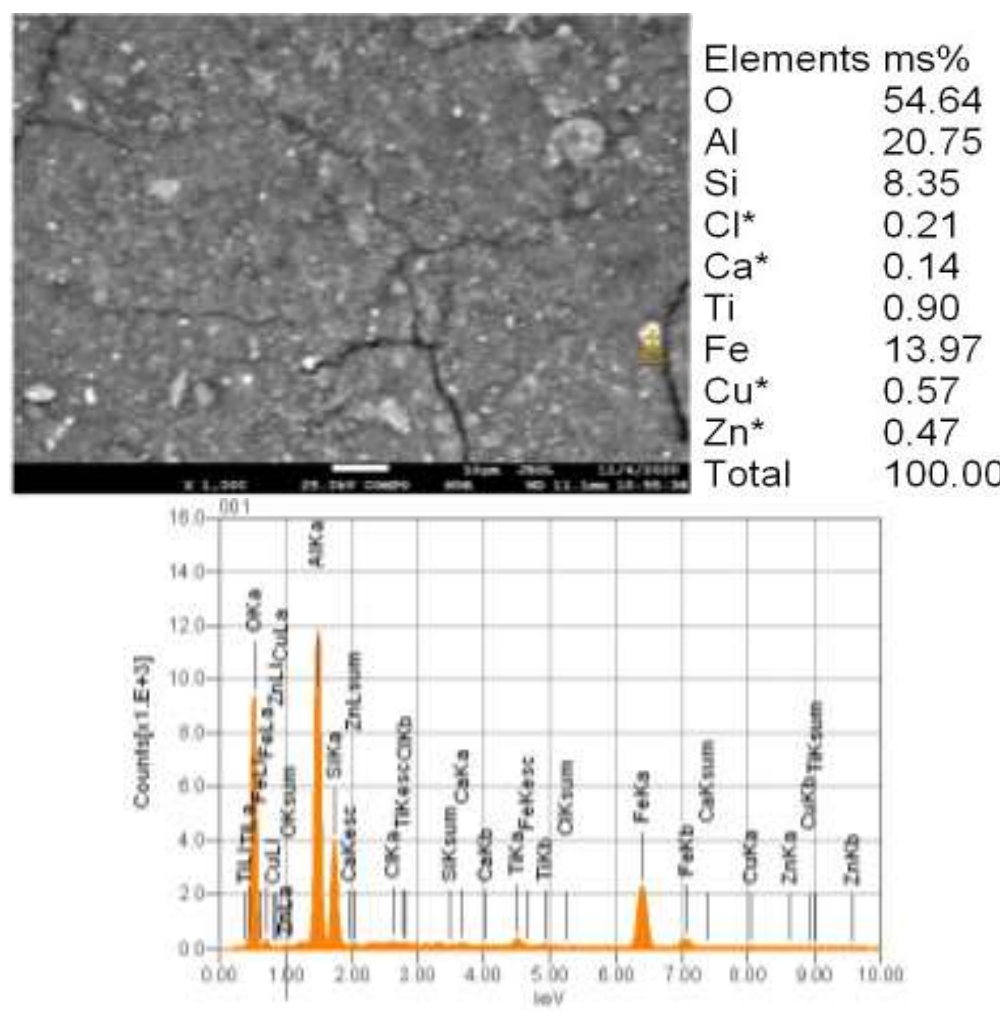

b

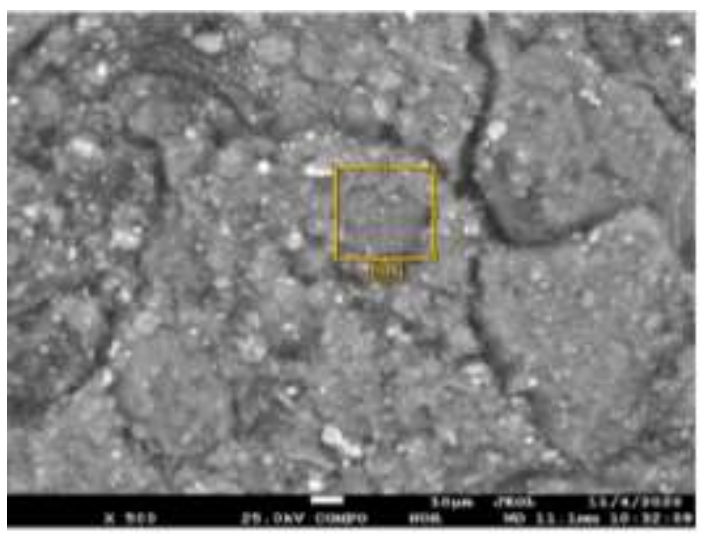

Elements $\mathrm{ms} \%$

O 66.07

Al 21.49

Si $\quad 4.87$

$\mathrm{Cl}^{*} \quad 0.15$

$\mathrm{Ca}^{*} \quad 0.14$

$\mathrm{Ti} \quad 0.75$

$\mathrm{Fe} \quad 5.36$

$\mathrm{Cu}^{*} \quad 0.65$

$\mathrm{Zn}^{*} \quad 0.50$

Total $\quad 100.00$

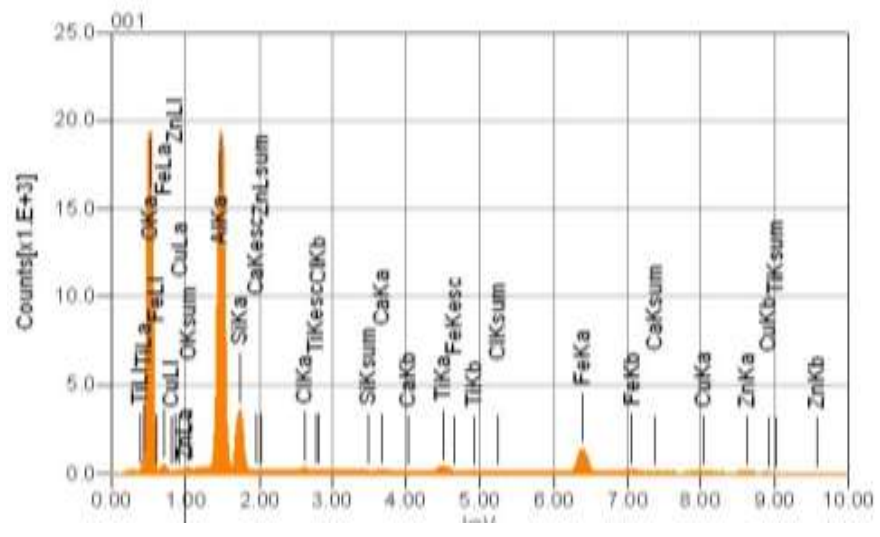

C

$a$ - general composition; $b$ - coarse fraction; $c$ - a fine fraction

Figure 3. Microphotographs and electron microscopic analyzes of a bauxite sample 
The microphotographs show that the coarse-grained bauxite fraction is tightly pressed by the fine fraction. The total silicon modulus of the sample section (Figure $3-a$ ) is 3.45 . The silicon modulus of the coarse fraction (Figure 3-b) is 4.41, and that of the fine fraction (Figure 3-c) is 2.19.

To increase the silicon modulus of bauxite by separating the fine fraction, the initial sample was chemically activated in sodium hydrocarbonate solution.

Determining the optimal conditions for the chemical activation of bauxite included the studies of the effect of temperature and process duration.

The effect of the chemical activation temperature on the change in the material composition of bauxite was studied at temperatures of $90-200^{\circ} \mathrm{C}$ for 60 minutes.

Table 2 illustrates the chemical composition of the bauxite sample depending on the activation temperature.

Table 2. Chemical composition of the bauxite sample depending on the activation temperature

\begin{tabular}{|c|c|c|c|c|c|c|}
\hline \multirow{2}{*}{ Name } & \multicolumn{6}{|c|}{ Activation temperature, ${ }^{\circ} \mathrm{C}$} \\
\hline & Init. & 90 & 120 & 150 & 180 & 200 \\
\hline & \multicolumn{6}{|c|}{ Content, $\%$} \\
\hline $\mathrm{Al}_{2} \mathrm{O}_{3}$ & 42.0 & 42.4 & 42.0 & 42.2 & 42.6 & 42.8 \\
\hline $\mathrm{SiO}_{2}$ & 11.5 & 11.4 & 11.3 & 11.3 & 11.4 & 11.5 \\
\hline $\mathrm{Fe}_{2} \mathrm{O}_{3}$ & 19.5 & 19.7 & 19.9 & 19.7 & 19.9 & 19.9 \\
\hline $\mathrm{CaO}$ & 1.08 & 1.1 & 1.1 & 1.2 & 1.1 & 1.2 \\
\hline $\mathrm{Na}_{2} \mathrm{O}$ & 0.22 & 0.7 & 1.06 & 1.18 & 1.5 & 6.4 \\
\hline $\mathrm{MgO}$ & 0.18 & 0.18 & 0.19 & 0.17 & 0.19 & 0.18 \\
\hline $\mathrm{SO}_{3}$ & 0.24 & 0.17 & 0.18 & 0.18 & 0.19 & 0.16 \\
\hline $\mathrm{K}_{2} \mathrm{O}$ & 0.03 & 0.03 & 0.02 & 0.03 & 0.05 & 0.05 \\
\hline $\mathrm{TiO}_{2}$ & 2.05 & 2.25 & 2.3 & 2.2 & 2.1 & 2.2 \\
\hline $\mathrm{Cl}^{-}$ & 0.04 & 0.02 & 0.02 & 0.016 & 0.017 & 0.03 \\
\hline p.p. & 23.16 & 22.05 & 21.93 & 21.824 & 20.953 & 15.58 \\
\hline
\end{tabular}

The chemical activation demonstrated that the element content in the samples remained at the same level, except for sodium oxide. At an activation temperature of $200^{\circ} \mathrm{C}$, a thick pulp was obtained.

Table 3 illustrates the phase composition of the bauxite sample depending on the chemical activation temperature.

Table 3. The phase composition of the bauxite sample depending on the chemical activation temperature

\begin{tabular}{|c|c|c|c|c|c|c|}
\hline \multirow{2}{*}{ Name } & \multicolumn{6}{|c|}{ Activation temperature, ${ }^{\circ} \mathrm{C}$} \\
\hline & Init. & 90 & 120 & 150 & 180 & 200 \\
\hline & \multicolumn{6}{|c|}{ Content, \% } \\
\hline Gibbsite $\mathrm{Al}(\mathrm{OH})_{3}$ & 54.95 & 55.59 & 56.45 & 55.7 & 52.38 & 55.34 \\
\hline Kaolinite-1A & 15.19 & 12.11 & 12.43 & 12.44 & 10.79 & 10.86 \\
\hline Siderite $\mathrm{FeCO}_{3}$ & 6.09 & 11.52 & 9.77 & 7.69 & 6.82 & 7.29 \\
\hline Quartz $\mathrm{SiO}_{2}$ & 5.11 & 4.8 & 4.91 & 6.37 & 7.63 & 8.04 \\
\hline Calcium & 5.07 & - & - & - & - & - \\
\hline Hematite $\mathrm{Fe}_{2} \mathrm{O}_{3}$ & 4.89 & 5.09 & 5.89 & 6.23 & 6.99 & 7.22 \\
\hline Titanium oxide $\mathrm{Ti}_{6} \mathrm{O}_{11}$ & 4.88 & 4.69 & 4.59 & 4.57 & 4.51 & 4.64 \\
\hline Ferrotitanium oxide & 3.82 & 3.67 & 3.70 & 3.80 & 3.76 & 3.41 \\
\hline Calcite $\mathrm{CaCO}_{3}$ & - & 2.53 & 2.26 & 3.20 & 3.21 & 3.20 \\
\hline
\end{tabular}


As follows from Table 3, with increasing chemical activation temperature in the phase composition of bauxite, the content of kaolinite and siderite decreases, the content of quartz and hematite increases, the phase of calcium silicate disappears, and the phase of calcite is formed.

The effect of the chemical activation duration on the change in the material composition of the bauxite sample at temperatures of 120 and $200^{\circ} \mathrm{C}$ was studied (Table 4).

Table 4. Chemical composition of the bauxite sample depending on the duration of activation at a temperature of $120^{\circ} \mathrm{C}$

\begin{tabular}{|c|c|c|c|c|c|c|c|}
\hline \multirow{2}{*}{ Name } & \multicolumn{6}{|c|}{ Duration, min. } & \multirow[b]{2}{*}{240} \\
\hline & 20 & 40 & 60 & 90 & 120 & 180 & \\
\hline \multicolumn{8}{|c|}{ Content, \% } \\
\hline $\mathrm{Al}_{2} \mathrm{O}_{3}$ & 42.2 & 42.25 & 42.24 & 42.4 & 42.4 & 38.8 & 36.3 \\
\hline $\mathrm{SiO}_{2}$ & 11.2 & 11.1 & 11.3 & 11.3 & 11.1 & 10.9 & 10.6 \\
\hline $\mathrm{Fe}_{2} \mathrm{O}_{3}$ & 20.3 & 20.3 & 19.8 & 19.6 & 20.0 & 18.6 & 17.1 \\
\hline $\mathrm{CaO}$ & 1.3 & 1.14 & 1.1 & 1.1 & 1.17 & 1.06 & 0.9 \\
\hline $\mathrm{Na}_{2} \mathrm{O}$ & 0.413 & 0.45 & 1.16 & 1.3 & 1.43 & 4.35 & 6.8 \\
\hline $\mathrm{MgO}$ & 0.13 & 0.18 & 0.19 & 0.16 & 0.18 & 0.2 & 0.16 \\
\hline $\mathrm{SO}_{3}$ & 0.19 & 0.16 & 0.18 & 0.17 & 0.17 & 0.04 & 0.19 \\
\hline $\mathrm{K}_{2} \mathrm{O}$ & 0.07 & 0.06 & 0.02 & 0.04 & 0.03 & 0.04 & 0.06 \\
\hline $\mathrm{TiO}_{2}$ & 2.5 & 2.4 & 2.6 & 2.2 & 2.5 & 2.2 & 2.06 \\
\hline $\mathrm{Cl}^{-}$ & 0.02 & 0.02 & 0.02 & 0.02 & 0.02 & 0.02 & 0.04 \\
\hline p.p. & 21.677 & 21.94 & 21.39 & 21.71 & 21.0 & 23.79 & 25.79 \\
\hline
\end{tabular}

The increased duration of activation to 180 minutes at a temperature of $120^{\circ} \mathrm{C}$ increases the $\mathrm{Na}_{2} \mathrm{O}$ content in bauxite, while the content of other elements remains at the same level. With an activation duration of 180 minutes or more, a thick pulp is obtained; its mass is greater than the initial mass of bauxite, so the percentage of elements decreases.

Table 5 illustrates the phase composition of the bauxite sample depending on the duration of chemical activation at a temperature of $120^{\circ} \mathrm{C}$.

Table 5. The phase composition of the bauxite sample depending on the duration of chemical activation at a temperature of $120^{\circ} \mathrm{C}$

\begin{tabular}{|c|c|c|c|c|c|c|c|}
\hline \multirow{2}{*}{ Name } & \multicolumn{7}{|c|}{ Activation temperature, ${ }^{\circ} \mathrm{C}$} \\
\hline & 20 & 40 & 60 & 90 & 120 & 180 & 240 \\
\hline & \multicolumn{7}{|c|}{ Content, \% } \\
\hline Gibbsite $\mathrm{Al}(\mathrm{OH})_{3}$ & 51.43 & 51.42 & 51.45 & 51.91 & 50.69 & 45.62 & 43.76 \\
\hline Kaolinite-1A AL $\mathrm{Si}_{2} \mathrm{O}_{5}(\mathrm{OH})_{4}$ & 11.67 & 11.98 & 10.94 & 10.22 & 10.37 & 9.06 & 9.3 \\
\hline Siderite $\mathrm{FeCO}_{3}$ & 4.89 & 4.58 & 4.77 & 5.00 & 6.56 & 6.02 & - \\
\hline Quartz $\mathrm{SiO}_{2}$ & 5.28 & 5.18 & 5.61 & 5.94 & 6.02 & 6.55 & 6.05 \\
\hline Calcium silicate $\mathrm{Ca}_{5} \mathrm{Si}_{3}$ & 10.02 & 10.25 & 10.23 & 10.1 & 9.81 & 9.35 & 8.09 \\
\hline Hematite $\mathrm{Fe}_{2} \mathrm{O}_{3}$ & 6.99 & 7.0 & 7.09 & 6.94 & 6.99 & 7.11 & 7.1 \\
\hline Titanium oxide $\mathrm{Ti}_{6} \mathrm{O}_{11}$ & 6.32 & 6.2 & 6.25 & 6.6 & 6.54 & 6.23 & 6.71 \\
\hline Ferrotitanium oxide $\mathrm{Fe}_{2} \mathrm{TiO}_{5}$ & 3.4 & 3.39 & 3.66 & 3.29 & 3.02 & 4.4 & 4.5 \\
\hline Calcite $\mathrm{CaCO}_{3}$ & - & 2.53 & 2.26 & 3.20 & 3.21 & 3.20 & \\
\hline Dawsonite $\mathrm{NaAlCO}_{3}(\mathrm{OH})_{2}$ & - & - & - & - & - & 5.66 & 14.49 \\
\hline
\end{tabular}


As a result of the chemical activation, the gibbsite phase content remains at the same level for up to 120 minutes, whereafter its amount decreases, and a new aluminum-containing phase - dawsonite - is formed.

Table 6 shows the chemical composition of the bauxite sample depending on the activation duration at a temperature of $200^{\circ} \mathrm{C}$.

Table 6. Chemical composition of the bauxite sample depending on the activation duration at a temperature of $200^{\circ} \mathrm{C}$

\begin{tabular}{ccccc}
\hline \multirow{2}{*}{ Name } & \multicolumn{5}{c}{ Duration, min. } \\
\cline { 2 - 5 } & $\mathbf{2 0}$ & $\mathbf{4 0}$ & $\mathbf{6 0}$ & $\mathbf{9 0}$ \\
\hline & \multicolumn{4}{c}{ Content, \% } \\
\hline $\mathrm{Al}_{2} \mathrm{O}_{3}$ & 44.1 & 44.38 & 44.83 & 44.8 \\
$\mathrm{SiO}_{2}$ & 11.0 & 11.1 & 10.9 & 10.7 \\
$\mathrm{Fe}_{2} \mathrm{O}_{3}$ & 20.1 & 19.4 & 19.9 & 11.08 \\
$\mathrm{CaO}_{\mathrm{Na}}$ & 1.14 & 1.1 & 1.2 & 0.6 \\
$\mathrm{MgO}_{2}$ & 0.2 & 0.9 & 6.4 & 23.1 \\
$\mathrm{SO}_{3}$ & 0.18 & 0.18 & 0.18 & 0.12 \\
$\mathrm{~K}_{2} \mathrm{O}$ & 0.17 & 0.17 & 0.16 & 0.2 \\
$\mathrm{TiO}_{2}$ & 0.04 & 0.05 & 0.05 & 0.01 \\
$\mathrm{Cl}^{-}$ & 2.6 & 2.53 & 2.5 & 1.64 \\
p.p. & 0.02 & 0.02 & 0.02 & 0.01 \\
& 20.45 & 20.17 & 13.86 & 7.74 \\
\hline
\end{tabular}

With an activation duration of 60 minutes, a thick pulp was obtained. At 90 minutes, a solid phase was obtained; it filled the entire volume of the autoclave.

The increase in the final weight of bauxite after activation at a temperature of $200^{\circ} \mathrm{C}$ and duration of 60 minutes or more resulted in a decrease in the element percentage, while the sodium oxide content increased sharply due to the formation of a new phase, namely, dawsonite (Table 7).

Table 7. The phase composition of the bauxite sample depending on the duration of chemical activation at a temperature of $200^{\circ} \mathrm{C}$

\begin{tabular}{|c|c|c|c|c|}
\hline \multirow{2}{*}{ Name } & \multicolumn{4}{|c|}{ Activation temperature, ${ }^{\circ} \mathrm{C}$} \\
\hline & 20 & 40 & 60 & 90 \\
\hline & \multicolumn{4}{|c|}{ Content, \% } \\
\hline Gibbsite $\mathrm{Al}(\mathrm{OH})_{3}$ & 54.59 & 54.38 & 50.34 & 15.3 \\
\hline Kaolinite-1 $\mathrm{A} \mathrm{AL}_{2} \mathrm{Si}_{2} \mathrm{O}_{5}(\mathrm{OH})_{4}$ & 9.58 & 8.85 & 9.8 & 6.34 \\
\hline Siderite $\mathrm{FeCO}_{3}$ & 8.8 & 8.86 & - & - \\
\hline Quartz $\mathrm{SiO}_{2}$ & 4.05 & 4.36 & 4.8 & 3.2 \\
\hline Calcium silicate $\mathrm{Ca}_{5} \mathrm{Si}_{3}$ & 5.45 & 6.28 & 6.22 & 5.45 \\
\hline Hematite $\mathrm{Fe}_{2} \mathrm{O}_{3}$ & 2.69 & 2.83 & 2.4 & 1.2 \\
\hline Titanium oxide $\mathrm{Ti}_{6} \mathrm{O}_{11}$ & 8.49 & 8.19 & 8.41 & 2.8 \\
\hline Ferrotitanium oxide $\mathrm{Fe}_{2} \mathrm{TiO}_{5}$ & 6.35 & 6.25 & 3.26 & 2.82 \\
\hline Calcite $\mathrm{CaCO}_{3}$ & - & - & 14.77 & 62.89 \\
\hline Dawsonite $\mathrm{NaAlCO}_{3}(\mathrm{OH})_{2}$ & - & - & - & - \\
\hline
\end{tabular}

The microphotographs and electron microscopic analysis of a bauxite sample after chemical activation are shown in Figure 4. 


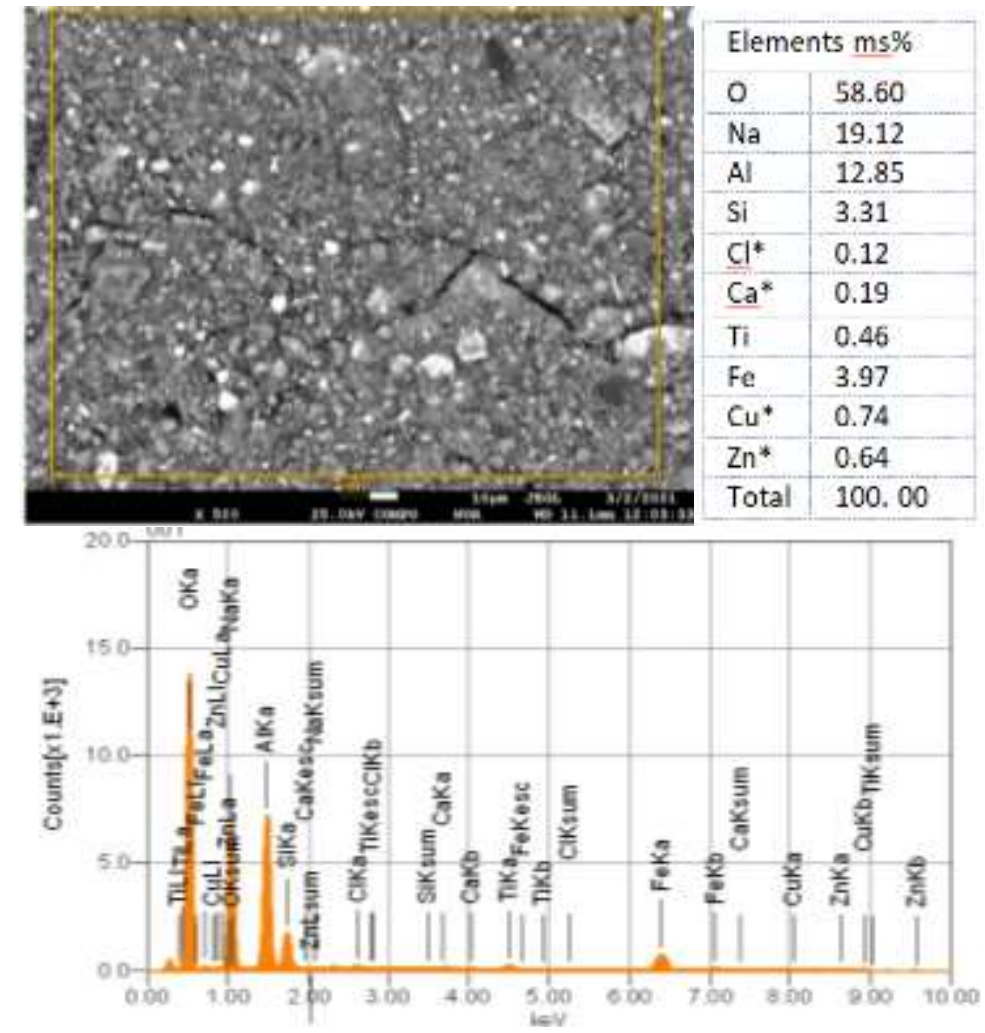

Figure 4. Microphotography and electron microscopic analysis of a bauxite sample after chemical activation at a temperature of $200^{\circ} \mathrm{C}$ and a duration of 40 minutes

The microphotograph shows that after the chemical activation of bauxite, the fine fraction separates from the coarse one, which will increase the efficiency of gravitational and chemical enrichment of the low-quality gibbsite-kaolinite bauxite from the Krasnogorsk deposit for further processing into alumina.

\section{Conclusions}

The phase composition of the gibbisite-kaolinite bauxite from the Krasnogorsk deposit is represented by gibbisite, kaolinite, siderite, hydroaluminosilicate, quartz, calcium silicate, hematite, titanium oxide, and ferrotitanium oxide.

The electron microscopic analysis of the initial bauxite showed that the coarse-grained bauxite fraction was tightly pressed by the fine one. The total silicon modulus of the sample is 3.45 . The silicon modulus of the fine fraction is 2.19 , and the silicon modulus of the coarse fraction is 4.41 .

As a result of the chemical activation of bauxite in the sodium hydrocarbonate solution, the fine fraction is effectively separated from the coarse fraction, and the phase composition changes, namely, the calcium silicate phase disappears, and the calcite phase is formed.

As the activation temperature increases, the content of kaolinite and siderite decreases, and the content of quartz and hematite increases.

A dawsonite phase is formed in bauxite at chemical activation temperatures of $120^{\circ} \mathrm{C}$, duration of more than 120 minutes, and $200^{\circ} \mathrm{C}$, duration of more than 40 minutes; it compacts the mineral structure and makes further enrichment by gravity methods impossible, therefore, when choosing the activation conditions, it is necessary to exclude the formation of this phase.

\section{Acknowledgments}

This work was based on grant financing \#AP08856046 and financial support from the Committee of Science of the Ministry of Education and Science of the Republic of Kazakhstan. 
Materials of International Practical Internet Conference "Challenges of Science", Issue IV, 2021

Cite this article as: Abdulvaliyev R.A.; Akcil A.; (2021). Change in the phase composition of low-quality bauxites as a result of chemical activation. Challenges of Science. Issue IV, 2021, pp. 67-75. https://doi.org/10.31643/2021.10

\section{Reference}

[1] Ibragimov A.T., Budon S.V. (2010). Development of technology for the production of alumina from bauxite in Kazakhstan. LLP "House of the press", 299. https://www.twirpx.com/file/2213812/ (in Russ).

[2] Kenzhaliyev B. K. Innovative technologies providing enhancement of nonferrous, precious, rare and rare earth metals extraction // Kompleksnoe Ispol'zovanie Mineral'nogo Syr’a (Complex Use of Mineral Resources). - 2019. - №3 (310). Page: 64-75. https://doi.org/10.31643/2019/6445.30 (In Eng.).

[3] Miryuk O.A. Activation of cement clinker with high content of belite // Kompleksnoe Ispol'zovanie Mineral'nogo Syr'a (Complex Use of Mineral Resources). - 2020. - № 2(313). p.38-45. https://doi.org/10.31643/2020/6445.15 (In Eng.).

[4] Ni LP, Medvedkov BE, Abdulvaliyev RA et al. (1987). Research on the processing of Krasnooktyabrsk bauxites with separate leaching of clay and rocky fractions // Processing of substandard raw materials for alumina: collection of articles. scientific. tr. IMOB SA KazSSR, 3-8. (in Russ).

[5] Patent No. 32333 RK. Method of preparation of aluminosilicate raw materials before leaching / Abdulvaliev R.A., Gladyshev S.V., Pozmogov V.A., Imangalieva L.M. publ. 31.08.2017, Bul. No. 16. (in Russ).

[6] Kenzhaliyev B.K., Imangalieva L.M., Manapova A.I., Azlan M.N. (2021). Kaolinite clays as a source of raw materials for the aluminum industry of the Republic of Kazakhstan. Kompleksnoe Ispol'zovanie Mineral'nogo Syr'a = Complex Use of Mineral Resources. Volume 4, Issue 319, pp. 5-12. https://doi.org/10.31643/2021/6445.34 (In Eng.). 